\title{
THE IMPOLITENESS IN THE CHARLIE PIPPIN: A PRAGMATIC STUDY
}

\author{
Waliyadin \\ LBB IPIEMS Semarang \\ waliyadin.nuridin@gmail.com
}

\begin{abstract}
The conflict because of impoliteness in using language happens recently in the school and family context. The case encourages the researcher to investigate the phenomena of impoliteness in communication. The types of impoliteness and the strategies used by a person in producing impolite utterance are investigated. Due to the lack of data sources depicted the conflict in the school and family naturally, the novel Charlie Pippin by Candy Dawson Boyd (1987) is used as the data sources. Culpeper's models of super strategies impoliteness $(1996,2005)$ are used as the theoretical framework. The finding shows that each character in the novel used different strategy of impoliteness according to their social level. The character has high social level often used bald on record impoliteness and positive impoliteness. This research support the previous research conducted by Mohammed (2016).
\end{abstract}

Keyword: Impoliteness, Charlie Pippin, Culpeper's Model of Impoliteness 


\section{INTRODUCTION}

The relation between teacher and students is not always harmonious. Conflicts between teacher and student sometimes happen. There are various factors that cause the conflict. One of them is the way of someone in using language. They use impolite language since they don't understand the language beyond the superficial level (the language in the discourse level). For example, on August, the conflict between teacher with student, and parent with teacher happened. One of the students parent come to the school and hit the teacher. This case happened because the parent objected with the teacher's treatment on his son. The teacher slapped the student since he uttered impolite word when the teacher asked to do homework (jppn.com, 11/8/2010).

From the case, all of us realize that politeness in communication and interaction is important. Yule (1996:59) in his book, Pragmatics, argued that using language is not only doing linguistic interaction but also social interaction. Inability to communicate politely in social interaction may give bad impact to the speaker and the interlocutor. In fact, the social disharmony becomes one of the bad impacts. Considering the importance of the polite communication, the knowledge regarding to the polite and impolite communication is needed. To understand more deeply about the politeness and impoliteness, one needs to study the linguistics. Pragmatics is one branch of linguistics that examines the politeness and impoliteness.

Study the politeness or impoliteness is important not only for the context of social life in the society but also for the school and family. Moreover, the phenomena of impoliteness often happened in the school and family as the case mentioned above. Considering the phenomena of impoliteness in communication, the researcher is curious to do research aimed at investigating the phenomena of impoliteness in communication that involves the interaction between teacher and students, teacher and parents.

In doing the investigation, the writer focuses on dialogue in a novel. Novel is chosen since there are still few researches on the phenomenon of impoliteness in the literary art in the form of novel. In addition, the novel that was analyzed represented the school 
and family life. Moreover, the characters of the novel represented racial issue. In fact the protagonist wasblack American girl where their characteristics triggered discrimination and stereotype.

The researcher was not alone in conducting this research meaning that there were several previous researches concerned on the impoliteness. Aulona Beqo (2015) carried out research on the theory of impoliteness. He analyzed the dialogue between Tana and Kote, the two female characters from "A 14 year oldgroom" written by Andon Z. Cajupi. The research aims to offer an analysis of therealization of the impoliteness theory. Mohammed and Abbas (2016) also conducted research on politeness particularly in the literary discourse. This research focuses on the phenomenon of pragmatic (ie. Impoliteness) in the play, Pygmalion, by the Irish playwright George Bernard Shaw.Culpeper's (2005) model of impoliteness was employed as the theoretical framework. In addition, Agustinus Hary Setyawan (2015) entitled "Kesopanan Tutur pada Rapat Politik Studi Kasus dalamPertuturan Margaret Thatcher dalam Film The Iron Lady". The purpose of this research are to describe the type of impoliteness and the way the character of Margareth Thatcher used the strategy of impoliteness.

Different from the previous research, the researcher used extract dialogue in the novel of Charlie Pippin. Even though the dialogue in the novel was not as natural as the dialogue in the extract of dialogue on TV, play, film, the dialogues in this novel still have qualifications to be the data sources of this research. Moreover the purpose of this research is not too concern on the development of the theory of the impoliteness. Instead, the concern of this research is on how phenomena of impoliteness can be understood and how the speaker uses strategies of impoliteness. Hopefully, the research can make us be aware of the phenomena of impoliteness and its strategy.

\section{BACKGROUND LITERATURE}

\subsection{Overview of Pragmatic}

The various definitions of pragmatics indicate that this branch of linguistics develop rapidly and it is interesting to be researched. 
Some definitions of pragmatics described in this research paper become the bridge to understand the concept of politeness or impoliteness. Yule (1996) defines pragmatics as firstly, "the study about the speaker intention", secondly, the study about contextual meaning. Thirdly, pragmatics is the study how information is delivered, which is more than the utterances. And the last, pragmatics is the study about the expression of relative distance (Yule, 1996.p.3)

Meanwhile, Cruse in Cummings, defines pragmatics by considering some aspects of information (in the wide meaning) conveyed through language, decoded by the convention accepted commonly in the linguistic form which is used but it is natural and depend on the meaning which is decoded conventionally with the context of the place (Cummings, 1999:2)

Alan Cruse defines pragmatics by comparing the pragmatics with semantics. According to Cruse, semantics is deal with the truth meaning according to the condition aspect while pragmatics is not accordance with the truth of the condition aspect. Secondly, semantics is deal with the contextual meaning which is independent while pragmatic is deal with the contexts in the deeper understanding that include previous utterance, participants in the speech event, interrelation among the participants, knowledge, goal and the background of the speech event. Thirdly, semantic is deal with conventional aspect of meaning where meaning is established between form and meaning while pragmatics deals with the aspect of meaning needed to be "worked out" through particular condition. The last, semantic is deal with the description of meaning while pragmatic is deal with the use of the meaning (Cruse, 2006:136)

Thomas and Leech (1983) differentiate two components of pragmatic namely socio-pragmatics and pragmalinguistic components. Pragmalinguistic deals with the aspect linguistics of pragmatic that include the sources used by the speaker in the communication such as pragmatic strategy (directness and indirectness), modification device while socio-pragmatics is related to the relation between linguistic action and social structure (cited in Mohammed, 2016).

Socio-pragmatic becomes the focus of this research paper particularly on the (im)politeness and interaction. When discussing po- 
liteness, it is inevitable to discuss impoliteness as well and vice versa. When persons are attributed to have politeness in communication and interaction they are successful to escape from the judgment of impoliteness and vice versa.

Discussing about (im)politeness is inevitable to the discussion about technical terms like face, face threatening acts, face saving acts, negative and positive face, bald on record and so forth. So, to be familiar with those terms, the definition of those terms are explained. Yule defines face as the public image of person. It refers to that emotional and social sense of self that everyone has and expects everyone else to recognize. Negative face is the need to be independent, to have freedom of action and not to be imposed on by others. Positive face is the need to be accepted even liked by other, to be treated as a member of some group and to know that his/her wants are shared by others. Face threatening act is what a speaker says that threats another individual's expectation regarding self image. Face saving act is the speaker's action to lessen the possible threat (Yule, 1996:60-61).

\subsection{Impoliteness}

The notion of impoliteness emerges after the theory of politeness introduced by Brown and Levinson. Since then, there are various definitions of impoliteness and they are very controversial (Aydınoğlu, 2013:473). Most of the definitions are centered on the notion of face. For instance, Brown and Levinson are inspired by the notion of face belongs to Goffman and the Grice's Maxim. They state that any behavior that attempts to protect the face of addresseee is polite; therefore any behavior that attacks the face of addresseee is impolite (Aydınoğlu,2013:473). The notion face later becomes the central of the definition of impoliteness.

Culpaper (1996) defines impoliteness as "the use of strategies designed to attack face, and thereby cause socialconflict and disharmony". Then Culpeper gave a more specific account to impoliteness in his second definition (2005) which reads "impoliteness comes about when: (1) the speaker communicates a face-attack intentionally, or (2) the hearerperceives and/or constructs behavior as 
intentionally face-attacking, or a combination of (1) and (2)" (cited in Ruhi and Aksan, 2015, p. 41).

In the latest book of Impoliteness: Using Language to Cause Offence, Culpaper gave additional component of impoliteness as follows:

a. Speaker's words conflict with Hearer's social norm-based expectations of how Speaker should be addressing Hearer;

b. Speaker's words cause or are presumed to cause the perlocutionary effect of offence (i.e., negative emotional consequences) for at least Hearer;

c. other factors (such as intentionality) can exacerbate offence, but are not necessary conditions;

d. and these perceptions are context-dependent. (Culpaper, 2011).

Besides, Bousfield in his book entitled Impoliteness and Interaction defines:

impoliteness is to be the broad opposite of politeness, in that, rather than seeking to mitigate face-threatening acts (FTAs), impoliteness constitutes the communication of intentionally gratuitous and conflictive verbal face-threatening acts (FTAs) which are purposefully delivered: i. Unmitigated, in contexts where mitigation is required, and/or, i. With deliberate aggression, that is, with the face threat exacerbated, 'boosted', or maximized in some way to heighten the face damage inflicted.

Different from the previous definitions, Sara Mills argues that "rather than assuming that there is something intrinsically impolite about certain utterances or exchanges, impoliteness is attributed to a speaker on the basis of assessments of their intentions and motivations". According to her, impoliteness is the complex matter so that the judgment of person's behavior as impolite is not easy. She offers the new dimension of impoliteness called community in practice. She argues that there are many factors to assess that person judged as impolite. The factors include gender stereotype, race, ethnic, etc. (Mills, 2003:149)

\subsection{Culpeper's model of super strategy of impoliteness}

Culpaper conducted many researches on impoliteness. From 
his research, he resulted the model of super strategy impoliteness. The first model was introduced in 1996 and then in 2005 he revised and added some components of the research. In 2011, he also completed the model of super strategy impoliteness with some components and sub strategy especially on the dimension of intentionality and social norm.

The following are the Culpeper's model of super strategies impoliteness (1996) and some additional components of Culpaper's model (2005). The following models are cited in Bousfield's book of Impoliteness and Interaction (2008:90)

1. Bald on record impoliteness super strategy are typically deployed where there is much face at stake, where there is an intention of the speaker to attack the face of the hearer.

2. Positive impoliteness (Culpeper, 1996) cited in Bousfield, 2008)

Culpapaper suggests that this strategy exists for the use of strategy designed to damage the addressee's positive face wants. The linguistic output strategy include:

a. ignore, snub, fail to attend to H's interest, wants, needs, goods, etc.

b. Exclude the other from activity

c. Dissociate from other, deny common ground or association

d. Be disinterested, unconcerned, unsympathic

e. Use inappropriate identity markers

f. Use obscure or secretive language

g. Seek disagreement-sensitive topics or just disagree outright

h. Avoid agreement—avoid agreeing with H's position (whether $\mathrm{S}$ actually does or not)

i. Make other feel uncomfortable

j. Use taboo language_-swear, be abusive express strong views opposed to H's

k. Call H's name-use derogatory nomination, or call the other name

\section{Negative impoliteness}

The use of strategy designed to damage the addressee's negative face want. Negative face means the want of every competent 
adult member that his or her action is unimpeded by others. The linguistic output strategies include:
a. 2.1 frighten
b. 2.2 condescend, scorn, ridicule
c. 2.3 invade the other's space-literally (positioning closer than the relationship permits); or metaphorically (ask intimate infor- mation given the relationship)
d. 2.4 explicitly associate $\mathrm{H}$ with negative aspect—personalize, use pronoun 'I' and 'You'
e. 2.5 put $\mathrm{H}$ indebtedness
f. 2.6 hinder-physically (block passage), conversationally (deny turn, interrupt)

\section{Sarcasm or Mock Impoliteness}

For culpaper (1996) sarcasm or mock politeness is a supra strategy in its own right. Here face threatening acts are performed with the use of politeness strategy that obviously insincere, and thus remain surface realization sarcasm. In other words, sarcasm means the use of one or more sub-strategies which are superficially suitable and accepted but deeply they have the opposite meaning (Bousfiled, 2008). Culpeper (2005) changed sarcasm or mock politeness became of record impoliteness where offence is conveyed indirectly by way of implicature and could be cancelled.

\section{Withhold politeness}

Keep silent when politeness work is expected, necessary or mandatory and hence damage the hearer's face. For example; failing to thank someone for a present may be taken as deliberate impoliteness (Bousfield, 2008:122)

\section{METHODS}

This research is aimed at describing the phenomena of impoliteness in literary work of novel entitled Charlie Pippin by Candy Dawson Boyd. This research emphasize on the strategies impoliteness used by the characters in the novel particularly in the conflictive dialogue. Culpeper's models of impoliteness become the theoretical 
framework to analyze the phenomena of impoliteness depicted in the novel.

This present research used qualitative approach. According to Crasswell cited by Asri Dwi E.S, qualitative approach concern on the natural phenomena. The researcher becomes the main instrument of data collection that compiles the words, analysess the data inductively, concern with the meaning of participants and describe an expressive language process (Asri Dewi E.S, 2015. p.250). To implement this research, the researcher collected the data by reading the novel as the main data sources and purposively took the dialogues that contain conflicts and impolite utterances. Then, the researcher classified the utterances based on the form, producer and type of Culpaper's strategy of impoliteness.

The extracts of dialogue in this research are compiled from the conversation between Charlie as the main character (protagonist), Mr.Pippin and Mrs. Hayamoto as the (antagonist) and additional character as Mrs. Pippin and Sienna. The extract dialogue in the chapter 1 is chosen since the dialogues are conflictive and contain impolite utterance. The dialogue also depicts the classroom interaction between teacher and student. The extract dialogue in the chapter 2 and 3 are chosen since the dialogue describes the interaction between child and parents. The both dialogues are needed to be investigated since the purpose of the research is to describe the impoliteness in the school and family life.

\section{FINDINGS}

\section{The Selected Extract}

\section{- Extract Dialogue in Chapter 1 (p.3-4)}

[Charlie was in the classroom to have math test. Mrs. Hayamoto, the teacher of the class was busy organizing 30 students who are disruptive. While waiting for the class quiet, Charlie made Samurai hat. When she was working, Mrs. Hayamoto came and talked to Charlie in high intonation]

Mrs. Hayamoto: What are you doing, Chartreuse?

Charlie : Folding quietly until math starts

Mrs. Hayamoto: Put away and get out notebook paper. Write two hun- 
dred times, "I, Chartreuse Pippin, will concentrate only on my schoolwork". And you'll take a note home this afternoon. I want the note returned tomorrow morning signed by both of your parents.

Charlie : You're not being fair, Mrs. Hayamoto. What was I doing wrong?. I was only making samurai hats, not talking or bothering anybody.

Mrs. Hayamoto: Chartreuse, that's not the point. According to the Discipline code, you are supposed to be engaged in school work all the time, be a

Charlie : Responsible learner. I know all that. But you weren't teaching us anything.

Hayamoto : Don't back to me. Get busy, Charteuse

Charlie : My name is Charlie. I don't like Chartreuse

Mrs. Hayamoto: And I don't have time to learn nickname. Kathryn rose, Pass back the math tests. Get to work, Charteuse

\section{- Extract dialogue in the chapter 2 (p. 23)}

Context: [Charlie met her father, She knew that her father was mad of her since He got call from school principal because of her daughter's acts at school]

Mr. Pippin : Put that stupid dog down! And don't open your mouth! I don't want to hear anything you have to say. Give me a pen, Eleanor

Charlie : Daddy, I wasn't talking or bothering anybody

Mrs. Pippin : Come on, Oscar, don't be so hard to Charlie. She'll outgrow this stage just like all others

Mr. Pipin $\quad$ :I am taking away your television privileges. You hear me. You are just as irresponsible as that do nothing uncle you love so much

Mrs. Pippin : Oscar, don't bring my brother, Ben into this

Mr. Pipin : A man comes home for a little peace, and look what he gets. All I want to hear from you, Charlie, is Daddy I will obey the school rules

Charlie : Daddy, I'll follow the school rules 
The Impoliteness in the Charlie Pippin ...

Mr.Pippin : Obey!

Charlie : Obey

- Extract dialogue in the chapter 3 (p.29)

Mr.Pippin : [Mr.Pippin threatened] Don't you cover your ears! I'll knock those hands down!

Charlie : [charlie jerked up and clasped her hands tightly] Daddy, please

Mr. Pippin : Please, What?. What kind of daughter are you? Why can't you behave like your sister?

\section{- Extract dialogue in the chapter 3 (p.31)}

[Charlie was mad. And she thought about how father treated Sienna, never raising his voice or calling her mean names, the anger bubbled out] Charlie

: "You never treat Sienna like this!" [she yelled back at him, amazed that such hard, hot words were leaving her mouth]. "I wish Uncle Ben was my Daddy. Not You! I hate you just like you hate me!"

Sienna : You okay? [sienna asked] what did you do this time? Rob a bank?

Charlie : No, I didn't rob any stupid bank! And if you are going to tease me, just leave!

Based on the data analysis, the finding of the research are summarized in the following table. Table 1. The impolite utterence, strategies and sub strategies of impoliteness.

\begin{tabular}{|c|c|c|c|c|}
\hline No & Utterence & Form & $\begin{array}{c}\text { Pro- } \\
\text { ducer }\end{array}$ & $\begin{array}{c}\text { Type of super } \\
\text { strategy }\end{array}$ \\
\hline 1 & $\frac{\text { What are you doing, }}{\text { Chartreuse? }}$ & $\begin{array}{c}\text { Sen- } \\
\text { tence }\end{array}$ & $\begin{array}{c}\text { Mrs. } \\
\text { Haya- } \\
\text { moto }\end{array}$ & $\begin{array}{c}\text { Positive impo- } \\
\text { liteness; ex- } \\
\text { clude someone } \\
\text { from activity }\end{array}$ \\
\hline 2 & $\begin{array}{c}\text { Folding quietly until } \\
\text { math starts }\end{array}$ & Clause & Charlie & $\begin{array}{c}\text { Face saving } \\
\text { act* }\end{array}$ \\
\hline
\end{tabular}




\begin{tabular}{|c|c|c|c|c|}
\hline 3 & $\begin{array}{l}\text { Put away and get out } \\
\text { notebook paper. Write } \\
\text { two bundred times, "I, } \\
\text { Chartreuse Pippin, } \\
\text { will concentrate only } \\
\text { on my schoolwork". } \\
\text { And you'll take } \\
\text { a note home this } \\
\text { afternoon. I want } \\
\text { the note returned } \\
\text { tomorrow morning } \\
\text { signed by both of } \\
\text { your parents }\end{array}$ & $\begin{array}{l}\text { Sen- } \\
\text { tence }\end{array}$ & $\begin{array}{l}\text { Mrs. } \\
\text { Haya- } \\
\text { moto }\end{array}$ & $\begin{array}{l}\text { Bald on record } \\
\text { impoliteness }\end{array}$ \\
\hline 4 & $\begin{array}{l}\text { You're not being fair, } \\
\text { Mrs. Hayamoto . } \\
\text { What was I doing } \\
\text { wrong?. I was only } \\
\text { making samurai hats, } \\
\text { not talking or bothering } \\
\text { anybody }\end{array}$ & $\begin{array}{l}\text { Sen- } \\
\text { tence }\end{array}$ & Charlie & $\begin{array}{c}\text { Face saving } \\
\text { acts* }\end{array}$ \\
\hline 5 & $\begin{array}{l}\text { Chartreuse, that's not } \\
\text { the point. Accord- } \\
\text { ing to the Disci- } \\
\text { pline code, you are } \\
\text { supposed to be } \\
\text { engaged in school } \\
\text { work all the time, } \\
\text { be a }\end{array}$ & $\begin{array}{l}\text { Sen- } \\
\text { tences }\end{array}$ & $\begin{array}{l}\text { Mrs. } \\
\text { Haya- } \\
\text { moto }\end{array}$ & $\begin{array}{l}\text { Positive impo- } \\
\text { liteness; seek } \\
\text { disagreement }\end{array}$ \\
\hline 6 & $\begin{array}{l}\text { Responsible learner. } \\
\text { I know all that. } \underline{B u t} \\
\text { you weren't teaching us } \\
\text { anything }\end{array}$ & $\begin{array}{l}\text { phrase, } \\
\text { sen- } \\
\text { tence }\end{array}$ & Charlie & $\begin{array}{c}\text { a.Negative } \\
\text { impoliteness; } \\
\text { Hinder (int- } \\
\text { erupt) } \\
\text { b.Bald on record } \\
\text { impoliteness }\end{array}$ \\
\hline
\end{tabular}


The Impoliteness in the Charlie Pippin ...

\begin{tabular}{|c|c|c|c|c|}
\hline 7 & $\begin{array}{c}\text { Don't back to me. } \\
\text { Get busy, Charteuse }\end{array}$ & $\begin{array}{c}\text { Sen- } \\
\text { tence }\end{array}$ & $\begin{array}{c}\text { Mrs. } \\
\text { Haya- } \\
\text { moto }\end{array}$ & $\begin{array}{c}\text { Positive impo- } \\
\text { liteness; Call H } \\
\text { name }\end{array}$ \\
\hline 8 & $\begin{array}{c}\text { My name is Charlie. } \\
\text { I don't like Char- } \\
\text { treuse }\end{array}$ & $\begin{array}{c}\text { Sen- } \\
\text { tence }\end{array}$ & Charlie & $\begin{array}{c}\text { Positive impo- } \\
\text { liteness; disag- } \\
\text { grement }\end{array}$ \\
\hline $\begin{array}{c}\text { And I don't have time } \\
\text { to learn nickname. } \\
\text { Kathryn rose, Pass } \\
\text { back the math tests. } \\
\text { Get to work, Char- } \\
\text { teuse }\end{array}$ & Sen- & $\begin{array}{c}\text { Mrs. } \\
\text { tence }\end{array}$ & $\begin{array}{c}\text { Haya- } \\
\text { moto } \\
\text { Positive impo- } \\
\text { liteness; ignore }\end{array}$ & \\
\hline
\end{tabular}

- Extract in Chapter 2

\begin{tabular}{|c|c|c|c|c|}
\hline No & Utterence & Form & $\begin{array}{l}\text { Pro- } \\
\text { ducer }\end{array}$ & $\begin{array}{l}\text { Type of Su- } \\
\text { per strategy } \\
\text { impolite- } \\
\text { ness }\end{array}$ \\
\hline 10 & $\begin{array}{l}\text { Put that stupid dog } \\
\text { down! And don't } \\
\text { open your mouth! I } \\
\text { don't want to hear } \\
\text { anything you have to } \\
\text { say. Give me a pen, } \\
\text { Eleanor. }\end{array}$ & phrase & $\begin{array}{l}\text { Mr. Pip- } \\
\text { pin }\end{array}$ & $\begin{array}{c}\text { Positive } \\
\text { impoliteness; } \\
\text { Use taboo } \\
\text { language }\end{array}$ \\
\hline 11 & $\begin{array}{l}\text { Daddy, I wasn't } \\
\text { talking or bothering } \\
\text { anybody }\end{array}$ & $\begin{array}{l}\text { Sen- } \\
\text { tence }\end{array}$ & Charlie & $\begin{array}{c}\text { Face Saving } \\
\text { Acts* }\end{array}$ \\
\hline 12 & $\begin{array}{l}\text { Come on, Oscar, } \\
\text { don't be so hard to } \\
\text { Charlie. She'll out- } \\
\text { grow this stage just } \\
\text { like all others }\end{array}$ & $\begin{array}{l}\text { Sen- } \\
\text { tence }\end{array}$ & $\begin{array}{l}\text { Mrs. } \\
\text { Pippin }\end{array}$ & $\begin{array}{c}\text { Face Saving } \\
\text { Acts* }^{*}\end{array}$ \\
\hline
\end{tabular}




\begin{tabular}{|c|c|c|c|c|}
\hline 13 & $\begin{array}{c}\text { I am taking away your } \\
\text { television privilages. } \\
\text { You hear me. You are } \\
\text { just as irresponsible as } \\
\frac{\text { that do nothing uncle you }}{\underline{\text { love so much }}}\end{array}$ & $\begin{array}{c}\text { Sen- } \\
\text { tence }\end{array}$ & $\begin{array}{c}\text { Mr. Pip- } \\
\text { pin }\end{array}$ & $\begin{array}{c}\text { Explicitly } \\
\text { associate the } \\
\text { other with } \\
\text { a negative } \\
\text { aspect }\end{array}$ \\
\hline 14 & $\begin{array}{c}\text { Oscar, don't bring my } \\
\text { brother, Ben into this }\end{array}$ & $\begin{array}{c}\text { Mrs. } \\
\text { Pippin } \\
\text { for a little peace, and } \\
\text { look what he gets. } \\
\text { All I want to hear } \\
\text { from you, Charlie, is } \\
\text { Daddy I will obey the } \\
\text { school rules' }\end{array}$ & $\begin{array}{c}\text { Bald on re- } \\
\text { cord impo- } \\
\text { liteness }\end{array}$ \\
\hline 16 & $\begin{array}{c}\text { Daddy, I'll follow the } \\
\text { school rules }\end{array}$ & Mr. Pip- \\
pin & $\begin{array}{c}\text { Face Saving } \\
\text { Acts }\end{array}$ \\
\hline 17 & Obey! & Charlie & $\begin{array}{c}\text { Face saving } \\
\text { Acts }\end{array}$ \\
\hline 18 & Obey & Mr. Pip- & Fin \\
\hline
\end{tabular}

- Extract in the chapter 3

\begin{tabular}{|c|c|l|c|c|}
\hline No & Utterence & Form & $\begin{array}{c}\text { Pro- } \\
\text { ducer }\end{array}$ & $\begin{array}{c}\text { Type of su- } \\
\text { per strategy } \\
\text { impolite- } \\
\text { ness }\end{array}$ \\
\hline 19 & $\begin{array}{c}\text { Don't you cover your } \\
\text { ears! I'll knock those } \\
\text { hands down! }\end{array}$ & $\begin{array}{c}\text { Mr. Pip- } \\
\text { pin }\end{array}$ & $\begin{array}{c}\text { Negative } \\
\text { impoliteness; } \\
\text { frighten }\end{array}$ \\
\hline 20 & Daddy, please & Charlie & $\begin{array}{c}\text { Face saving } \\
\text { act* }\end{array}$ \\
\hline
\end{tabular}


The Impoliteness in the Charlie Pippin ...

\begin{tabular}{|c|c|l|l|c|}
\hline 21 & $\begin{array}{c}\text { Please, What?. What } \\
\text { kind of daughter are } \\
\text { you? Why can't you } \\
\text { behave like your sister? }\end{array}$ & Mr.Pippin & $\begin{array}{c}\text { a.Ridicule } \\
\text { b.Explicitly } \\
\text { associate } \\
\text { the other } \\
\text { with positive } \\
\text { aspect }\end{array}$ \\
\hline $\begin{array}{c}\text { 'Yienna like this!". "I } \\
\text { wish Uncle Ben was } \\
\text { my Daddy. Not You!I } \\
\text { bate you just like you } \\
\text { hate me!" }\end{array}$ & $\begin{array}{c}\text { You okay? What did } \\
\text { you do this time? Rob } \\
\text { a bank? }\end{array}$ & Charlie & $\begin{array}{c}\text { Mock Impo- } \\
\text { liteness }\end{array}$ \\
\hline & & Sienna & $\begin{array}{c}\text { Negative } \\
\text { impoliteness; } \\
\text { Ridicule }\end{array}$ \\
\hline
\end{tabular}

\section{DISCUSSION}

To make it is easier in the discussion of impoliteness phenemena depicted in the novel Charlie Pippin, the utterences are classified based on the super stretegies and substrategies of impoliteness as follow:

\section{Bald on record politeness}

From the data, there are three utterences that are appropriate with the type of Culpeper's strategy impoliteness namely the utterence number 3, 6b and 14. Mrs. Hayamoto produced utterences $\underline{P u t}$ away and get out notebook paper.Write two bundred times, "I, Chartreuse Pippin, will concentrate only on my schoolwork". The utterences are imperative that threats Charlie face. Charlie's Negative Face, in the previous utterence, has been attacked by Mrs. Hayamoto. The attack makes her face at stake. In the such condition, Mrs. Hayamoto get her to write "I, Chartreuse Pippin, will concentrate only on my schoolwork" as consequence of breaking school's Discipline Code. According to Yule, the imperative sentence (for the purpose of Face Threatening Act) 
can be classified as bald on record impoliteness (Yule, 1996. p.64).

Then, in the utterence 6b, Charlie use strategy bald on record impoliteness since she attack Mrs. Hayamoto dirrectly and clearly by the utternece of But you weren't teaching us anything. The utterence can be classified as the Face Attacking Act according to Culpaper's model of super strategy impoliteness (2005).

Likeawise, in the utterence 14, Mrs. Pippin used bald on record impoliteness to attack Mr. Pippin's Face because of his statement that ridicule Mrs. Pippin's brother, Bob. Mrs. Pipin attacked Mr. Pipiin's negative face.

\section{Positive Impoliteness}

\section{Exclude someone from activity}

In the utterence number 1, Mrs. Hayamoto scattered Charli's concentration, making a long samurai hat. Mrs. Hayamoto in her act attacked Charlie's negative face regarding her freedom to do herself activity.

\section{Seek disagreement}

Mrs. Hayamoto in the utterence number 5, that's not the point, used sub strategy of seek disagreemnet. Charlie explained the case of doing activity in the classroom persuasively. She argued that doing activity in the classroom except the school activity is not the matter since she didn't disturb the others. However, Mrs. Haymoto was tenacious with his argument, doing activity except school activity was restricted.

Then, the utterence number 7, Mrs. Hayamoto called Charlie by the name of Charteuse. Charlie preferred to be called Charlie rather than Charteuse. Calling the unwanted nick name of someone in certain culture can threat the Face and can be impolite. This is in accordance with the concept of social norm of Holmes at al (2008) and Culpaper (2011).

In the utterence number 9, Mrs. Hayamoto used sub strategy of ignore. He didn't care with Charlie's argument. He said, "I don't have time to learn nickname". The utterence is indded attack Charlie's 
positive face. She wanted Mrs. Hayamoto called her with the nick name she liked.

In the utterence number 10, Mr. Pippin used taboo words like stupid dog and your mouth. Taboo words are often used the strategy of impoliteness and the strategy is effective to make impolite impression.

Nevertheless, Sara Mills argued that not all of utterence intrinsically contains impolite impression (Mills, 2003). In certain community of practice the taboo word can be impolite but in the other community of practice the taboo word is polite.

\section{Negative Impoliteness}

In the strategy of negative impoliteness, Charlie used strategy of hinder particularly interupt Mrs. Hayamoto's turn talk. Charlie knew what would be said by her teacher. She knew that the teacher would say that student must be responsible. Charlie wanted to argue that to be responsible didn't mean she lost her freedom to expression.

Then, Mr.Pippin in the utterence number 13, You are just as irresponsible as that do nothing uncle you love so much, tried to attack Charlie by assocating Charlie with her uncle. This strategy can threat Charlie's face. In another utterence, Mr. Pippin associated Charlie with her sister, Sienna. Mr. Pippin said, "Please, What?. Why can't you behave like your sister?". Charlie objected to be compared with her sister. Sienna in the Charlie's eyes is the competitor since Mr.Pippin always admired Sienna otherwise Charlie was always blamed, ridiculed by him.

The other sub strategy of negative impoliteness is frighten. In the utterence number 19, Don't you cover your ears! I'll knock those hands down!.Mr. Pippin threat Charlie if she kept covering her ears by her two hands, he will knock her hand down. Charlie always covered her ears to avoid hearing the ridiculous words from her father.

Besides, in the utterence number 22, Mr.Pippin used strategy of ridicule. He said, "What kind of daughter are you?". The utterence indeed ridicule Charlie. In addition, the utterence number 23, Rob bank?, is also a ridicule strategy. It imposibble Charlie was robbing 
the bank since she was in her room. The phrase is indeed to ridicule Charlie.

\section{Sarcasm and Mock Impoliteness}

In the utterence no 22, Charlie used strategy of mock impoliteness, She said, Not you! in high intonation and she said that she hate her father assertively. Based on the context she was mad of his father since his father compared her with her sister. "Charlie was mad. And she thought about how father treated Sienna, never raising his voice or calling her mean names, the anger bubbled out"

The data obtained from this reaseach are not included in the theoretical framework about impoliteness since there are some utterences of Face Saving acts like the utterence prouduced by Mrs. Pippin, Charlie and Mr. Pippin also. Besides, there are also some super strategy and sub strategy of impoliteness appears in the dialogue such as Withhold, sub strategy of snub, use wrong identity markers etc.

\section{CONCLUSION}

Some types of Culpeper's model of super strategy iompoliteness appears in the dialogue of novel entitled Charlie Pippin. Based on the data analysis, the finding are as follow. Firstly, The bald on record impoliteness are used by the three chracters, Mrs. Hayamoto, Charlie, and Mr. Pippin. Secondly, Positive Politeness includes the sub strategy of exclude someone from activities, seek disagreement, Cal H's name, ignore, and use taboo word. Thirdly, Negative Impolitenes includes sub strategies of Hinder, Frighten, Ridicule, Explicitly associate the other with positive or negative aspect. The last, the super strategy used by the caharcter is Mock Impoliteness.

Mrs. Hayamoto uses the most strategy of positive impoliteness (4 times) and bald on record impoliteness. Mr. Pippin uses negative impoliteness and Bald on record impoliteness and sub strategi of positive impoliteness(used taboo word). Charlie uses bald on record, mock impoliteness, positive politeness particularly on seek disagreement. Besides, in dialogue there are also strategy of politeness Brown and Levinson. Mr. Pippin, Charlie, dan Mrs.Pippin in 
The Impoliteness in the Charlie Pippin ...

the utterence number $2,4,11,12,16,18,20$. It is proved that the study of impoliteness is inevitable with the politeness and vice versa.

This research finally conclude that each character in the novel uses different strategy of impoliteness according to their social level. The character that has high social level often use bald on record impoliteness and positive impoliteness like Mrs. Hayamoto and Mr. Pippin. This conclussion support the previous research conducted by Mohammed(2016). 


\section{REFERENCES}

Aydınoğlu, Nazife (2013). "Politeness and Impoliteness Strategies: An Analysis of Gender

Differences in Geralyn 1. Horton's plays".Procedia - Social and Behavioral Sciences 83

Beqo, Aulona (2015). "Impoliteness In: “A 14 Year Old Groom”By Andon Z. Çajupi”. Social and Natural Sciences Journal, Volume 9 , Issue 2.

Bousfiel, Derek (2008). Impoliteness and Interaction. Amsterdam: John Benjamins Publishing Company.

Boyd, Candy Dowson (1987). Charlie Pippin.Virginia: Puffin Books.

Cruse, Alan (2006). A Glosary of Semantic and Pragmatic. Edinburg: Edinburg university Press

Cummings, Louis. (1999). Pragmatics, A Multidisciplinary Perspective. New York: Oxford University Press.

Dewi E.S, Asri (2015). "An Analysis of Flouting Maxim In EFL Classroom Interaction". Journal Vision, Volume 4 Number 2.Yule, George (1996). Pragmatic. New York: Oxford University Press.

Mills, Sara (2003). Gender and Politeness. New York: Cambridge University Press. 
The Impoliteness in the Charlie Pippin ...

Mohammed, Hiba Nassrullah and Nawal Fadhil Abbas (2016). "Impoliteness in Literary Discourse: A Pragmatic Study". International Journal of Applied Linguistics \& EnglishLiterature. Vol. 5 No. 2; March.

Setyawan,Agustinus Hary (2015). "Prinsip-Prinsip Kesopanan pada Rapat Politik Margaret Thatcher dalam Film The Iron Lady" . Jurnal Sosio-Humaniora Vol. 6 No. 1 Mei. 